\title{
Seasonal Variation of Phytoplankton Cherthala-Aroor-Edakochi Coastal Belt of Kerala, India
}

\section{Vidya Vijayakumari, Gopal Prasad Thiruvananthapuram Kerala, India, 695581, \\ Study Area: Vembanad wetland, Kerala \\ Coordinates: $9^{\circ} 35^{\prime} \mathrm{N} ; 7^{\circ} 25^{\prime} \mathrm{E}$}

Department of Zoology, University of Kerala, Kariavattom,

Key words: Physico-chemical Parameters, Vembanad, Seafood industry, Sea Pollution

\section{Introduction:}

Phytoplanktons are plants (microscopic), drifting at the mercy of water current. They do not have control over their movements thus they cannot escape pollution in the environment Abowei et al. (2012). The distributions, abundance, species diversity and species composition of the phytoplankton are used to assess the biological integrity of the water body Begon et al. (2014). Planktons are very sensitive to the environment they live in and any alteration in the environment leads to change in plankton communities in terms of tolerance, abundance, diversity and dominance in the habitat. They react fast to the pollution in the aquatic environment. Therefore, plankton population observation may be used as a reliable tool for biomonitoring studies to assess the pollution status of aquatic bodies Davies et al. (2009). Phytoplanktons are also the diagnostic tools in assessing water quality and hydrological status Nwankwo, (2004). Its distribution, abundance and diversity reflect the physico-chemical conditions of aquatic ecosystem in general and its nutrient status, in particular, Anene, (2003). There has been much interest in the processes influencing the development of phytoplankton communities, primarily in relation to physico-chemical factors Akbay et al. (1999); Peerapornpisal et al. (1999). There are many detailed descriptions of phytoplankton succession being correlated with changes in environmental parameters particularly

\section{Abstract}

A seasonal variation of plankton and its relation to the physico-chemical parameters in Cherthala-AroorEdakochi coastal belt of Kerala, where maximum numbers of seafood processing industries are located is studied. The phytoplankton samples were collected from ten preselected sites. Nine of the selected sites were closely associated with the discharge mouth of seafood processing plants and one kept as the reference site which is free from the seafood plant discharge. From all the study sites, a total of 38,472 phytoplankton individuals belonging to 11 classes were identified on the basis of standard keys. The major classes obtained were Bacillariophyceae $(21,812$ individuals), Chlorophyceae (7111 individuals), Cyanophyceae (6118). The correlation analysis showed that physico-chemical parameters like DO, BOD, COD, transparency and $\mathrm{pH}$ significantly influenced the distribution of phytoplankton.

temperature, light, nutrients availability and mortality factors such as grazing and parasitism (Roelke \& Buyukates, 2002). Phytoplankton satisfies conditions to qualify as suitable indicators in that they are simple, capable of quantifying changes in water quality, applicable over large geographic areas and can also furnish data on background conditions and natural variability (Lee, 1999). Vembanad and Kol wetland are the third largest wetland system in India and are designated Ramsar sites. Vembanad wetlands, apart from their ecological, regional and economic importance serve as a sink for the disposal of waste from different sources. Several studies explained the pollution status of Vembanad lake from various sources including domestic and municipal sewage, fertilizer and pesticide residues, heavy metals, coconut retting, industrial effluents from oil refineries, fertilizer plants, and chemical industries (Rai et al, 1976; Remani et al., 1980; Saraladevi et al., 1979). There are about 287 seafood exporters in Kerala with 124 processing plants and 169 cold storages. Kerala accounted for 10,8616 ton valued at Rs.1524.12 crores sharing $17.7 \%$ in quantity and $18.2 \%$ in value of marine export from India (www.ksidc.org). The Kochi region has a vast majority of export processing plants within the state.81 out of the 91 registered exporters in Kerala are situated within the Kochi and Cherthala taluks (SIFFS, 2002). Effluents from fish and crustacean processing plants are generally characterized by high concentrations of

*Corresponding Author: vidyaveee@gmail.com 
nutrients, high levels of nitrogen content found as ammonia $\left(\mathrm{NH}_{3}-\mathrm{N} ; 29\right.$ to $\left.35 \mathrm{mg}^{\cdot} \mathrm{L}^{-1}\right)$, high total suspended solids ( 0.26 to $125,000 \mathrm{mg}^{\cdot} \mathrm{L}^{-1}$ ), increased biological oxygen demand (10 to $110,000 \mathrm{mg}^{\circ} \mathrm{L}^{-1}$ ) and chemical oxygen demand (496 to $140,000 \mathrm{mg} \cdot \mathrm{L}^{-1}$ ), and by the presence of sanitizers (AMEC Earth and Environmental Limited 2003). The direct discharge of waste from the seafood processing industries into the adjacent wetlands affects the aquatic life and thus may affect the whole food chain. Uncontrolled discharge of waste disturbs the natural self-purification capacity of the river. The fish processing effluents detrimentally affect the quality of water bodies (Hamid et al., 2010). Considering the aforementioned reasons, the present study has been formulated to understand the seasonal variation of phytoplankton in relation to the physico-chemical parameters in selected sites of Vembanad wetland.

\section{Materials and methods:}

The surface water samples were collected on a monthly basis from the ten pre-selected sites of Vembanad wetlands where the maximum numbers of processing plants have been started since a period of last two years (October 2010September 2012). Nine of the selected sites (S1-S9) were closely associated with the discharge mouth of the seafood processing plants wetlands and one kept as the reference site (S10) which was free from the seafood plant discharge. Phytoplankton samples were collected from the surface water using a conical net of mesh size $50 \mu \mathrm{m}$, for a period of two year on a monthly basis. A known volume (25 liters) of water is passed through the net and was collected in a $50 \mathrm{ml}$ plastic container. The labeled samples were preserved in $4 \%$ formalin solution at the site itself, labeled and brought to the laboratory. Taxonomic identification of plankton up to genus level was done using standard keys (Adoni, 1985; Newell \& Newell, 1986; Palmer, 1980; Santhanam et al., 1987). Quantitative analysis of plankton was done by employing Sedgewick-rafter cell counting chamber. One $\mathrm{ml}$ of filtered plankton sample was transferred to the counting chamber and counted using a binocular microscope and reported as units or organisms per milliliter (mL) APHA et al. (2005).

Season-wise correlation analysis was employed to determine the relationship between physico-chemical parameters and phytoplankton.

\section{Results and Discussions:}

During the study period, a total of 38,472 phytoplankton individuals belonging to 11 classes were reported from all the study sites. The taxonomic classes reported were Bacillariophyceae (21,812 individuals), Chlorophyceae (7111 individuals), Cyanophyceae (6118), Dinophyceae (2445 individuals), Euglenophyceae (511 individuals), Eustigmatophyceae (181 individuals), Rhodophyceae (92 individuals), Haptophyceae (79 individuals), Chrysophyceae (71 individuals), Cryptophyceae (30 individuals) and Dictyphyceae. The study reported dominance of Bacillariophyceae in all the nine sites ( $\left.\mathrm{S}_{1}-\mathrm{S} 9\right)$ compared to the reference site. This may be due to its tolerance to a wide range of physico-chemical parameters as reported by Ajuonu et al. (2011). Bellinger \& Siegee (2010) also reported that the abundance of Bacillariophyceae was a characteristic feature of a eutrophic environment. The class Chlorophyceae followed by Cyanophyceae were the next dominant groups. These classes showed the highest individuals in the polluted sites compared to the reference site (Table-1). According to Rawson (1956), oligotrophic lakes are typically rich in the Chlorophyceae. Cyanophyceae dominance and its blooms are the most visible symptom of accelerated eutrophication of lakes and reservoirs (Moss, 1995). The fourth dominant class reported during the study period was Dinophyceae and its dominance is a characteristic of polluted water (Palmer, 1980).

The Mean \pm SE of the different phytoplankton classes were tabulated and given as Tables-2 to 4 . To determine the extent of influence of the environmental factors on certain dominant classes of phytoplankton, season-wise correlation coefficients were calculated (Tables- 5 to 7 ). Various correlations between different phytoplankton classes were also done (Tables-8 to 10). In the current study, the phytoplankton group showed a few significant correlations with the physico-chemical parameters.

During post-monsoon season, Bacillariophyceae was highest in $S_{3}(154.50 \pm 24.25)$ and lowest in $S_{10}(44.38 \pm 12.38)$. The Dinophyceae was highest in S9 (23.75 \pm 4.75$)$ and lowest in S10 (0.25 \pm 0.25$)$. The Chlorophyceae was highest in S2 $(94.38 \pm 28.38)$ and lowest in S1o $(18.00 \pm 8.00)$. The Cyanophyceae was reported maximum at $\mathrm{S}_{5}(48.88 \pm 17.63)$ and minimum at $\mathrm{S}_{7}(11.63 \pm 4.13)$. During the post-monsoon season, the Bacillariophyceae showed a signif icant negative correlation with air temperature $(\mathrm{p}=-0.655)$, nitrate $(\mathrm{p}=-$ $0.252)$, silica $(\mathrm{p}=-0.202)$ and with $\mathrm{DO}(\mathrm{p}=-0.390)$. The Dinophyceae showed positive correlation with alkalinity ( $\mathrm{p}=\mathrm{o.617})$, hardness $(\mathrm{p}=0.470)$, BOD $(\mathrm{p}=0.805)$, COD $(\mathrm{p}=0.725)$, phosphate $(\mathrm{p}=\mathrm{o} .720)$, ammonia $(\mathrm{p}=0.57 \mathrm{o})$ and silica $(\mathrm{p}=0.518)$ while it showed a bleak negative correlation with $\mathrm{pH}(\mathrm{p}=-0.049)$ and transparency $\mathrm{p}=-0.789)$ and with DO $(\mathrm{p}=-0.728)$.

Chlorophyceae showed a positive correlation with light intensity $(\mathrm{p}=0.650)$ and negative correlation with air temperature $(\mathrm{p}=-0.733)$ while Cyanophyceae showed a significant positive correlation with $\mathrm{pH}(\mathrm{p}=0.659)$. During pre-monsoon season, Bacillariophyceae was highest in $\mathrm{S}_{1}(113.88 \pm 41.38)$ and lowest at $\mathrm{S}_{9}(53.63 \pm 19.88)$. The Dinophyceae was highest in S2 (12.00 \pm 3.25$)$ and lowest in S1o (o.75 \pm 0.50$)$. The Chlorophyceae was maximum in $\mathrm{S}_{2}$

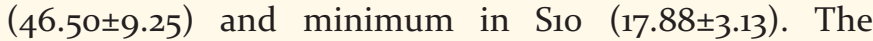
Cyanophyceae was highest in S2 $(82.88 \pm 42.63)$ and lowest in S8 $(15.13 \pm 7.88)$. In the pre-monsoon season, the phytoplankton group showed a few signif icant correlations 
Table 1: Family-wise Distribution of phytoplankton class in ten sites (S1 to S1o)

\begin{tabular}{|c|c|c|c|c|c|c|c|c|c|c|c|}
\hline Name of the Families & $\mathrm{S} 1$ & $\mathrm{~S}_{2}$ & $\mathrm{~S}_{3}$ & $\mathrm{~S}_{4}$ & $\mathrm{~S}_{5}$ & S6 & $\mathrm{S}_{7}$ & S8 & S9 & Sio & Total \\
\hline Bacillariophyceae & 2415 & 2255 & 3094 & 2770 & 2119 & 2265 & 1883 & 1922 & 1893 & 1196 & 21812 \\
\hline Dinophyceae & 219 & 241 & 401 & 199 & 316 & 247 & 274 & 159 & 370 & 19 & 2445 \\
\hline Chlorophyceae & 703 & 1271 & 863 & 833 & 696 & 620 & 632 & 499 & 566 & 428 & 7111 \\
\hline Chrysophyceae & o & 4 & 15 & 10 & 8 & 6 & 14 & 9 & 2 & 3 & 71 \\
\hline Dictyochophyceae & 1 & 2 & 6 & 2 & 2 & 4 & 1 & 3 & 1 & o & 22 \\
\hline Rhodophyceae & 10 & 8 & 4 & 3 & 8 & 13 & 15 & 10 & 7 & 14 & 92 \\
\hline Eustigmatophyceae & 8 & 57 & 25 & 27 & 32 & 8 & 3 & 16 & 4 & 1 & 181 \\
\hline Cryptophyceae & 6 & $\mathrm{o}$ & o & 7 & 3 & 2 & 7 & 4 & 1 & o & 30 \\
\hline Euglenophyceae & 37 & 25 & 61 & 72 & 54 & 43 & 36 & 76 & 106 & 1 & 511 \\
\hline Total & 4120 & 4847 & 5377 & 4653 & 3996 & 3742 & 3356 & 3041 & 3396 & 1944 & 38472 \\
\hline
\end{tabular}

Table 2: Distribution of different phytoplankton class (Mean \pm SE) during the post monsoon season

\begin{tabular}{lllll}
\hline Site & Bacillarioph. & Dinoph. & Chloroph. & Cyanoph. \\
\hline S1 & $97.50 \pm 22.25$ & $8.88 \pm 2.38$ & $28.88 \pm 13.88$ & $17.38 \pm 6.63$ \\
S2 & $144.63 \pm 38.38$ & $11.88 \pm 3.88$ & $94.38 \pm 28.38$ & $24.25 \pm 3.50$ \\
S3 & $154.50 \pm 24.25$ & $13.50 \pm 3.50$ & $42.75 \pm 2.50$ & $24.13 \pm 2.63$ \\
S4 & $142.00 \pm 28.75$ & $12.50 \pm 2.25$ & $41.38 \pm 6.13$ & $30.25 \pm 11.50$ \\
S5 & $132.38 \pm 32.13$ & $22.75 \pm 5.25$ & $41.63 \pm 6.38$ & $48.88 \pm 17.63$ \\
S6 & $116.88 \pm 5 \cdot 38$ & $14.25 \pm 3.25$ & $36.50 \pm 2.50$ & $13.50 \pm 1.50$ \\
S7 & $86.00 \pm 15.25$ & $16.38 \pm 5.13$ & $28.88 \pm 4.63$ & $11.63 \pm 4.13$ \\
S8 & $78.63 \pm 16.63$ & $10.13 \pm 1.13$ & $24.75 \pm 13.25$ & $13.38 \pm 2.38$ \\
S9 & $113.13 \pm 17.63$ & $23.75 \pm 4.75$ & $30.88 \pm 16.13$ & $18.25 \pm 3.00$ \\
S10 & $44.38 \pm 12.38$ & $0.25 \pm 0.25$ & $18.00 \pm 8.00$ & $12.13 \pm 10.88$ \\
\hline
\end{tabular}

Table 3: Distribution of different phytoplankton class (Mean \pm SE) during he pre monsoon season

\begin{tabular}{lllll}
\hline Site & Bacillarioph. & Dinoph. & Chloroph. & Cyanoph. \\
\hline S1 & $113.88 \pm 41.38$ & $10.38 \pm 4.88$ & $40.38 \pm 9.13$ & $28.38 \pm 13.62$ \\
S2 & $93.25 \pm 18.75$ & $12.00 \pm 3.25$ & $46.50 \pm 9.25$ & $82.88 \pm 42.63$ \\
$S_{3}$ & $84.38 \pm 21.38$ & $11.00 \pm 3.00$ & $25.50 \pm 7.25$ & $42.75 \pm 18.75$ \\
$S_{4}$ & $93.75 \pm 15.25$ & $7.25 \pm 1.50$ & $33.25 \pm 8.50$ & $23.88 \pm 4.63$ \\
S5 & $73.88 \pm 23.88$ & $9.63 \pm 5.88$ & $25.75 \pm 10.50$ & $17.50 \pm 6.25$ \\
S6 & $72.00 \pm 19.50$ & $9.75 \pm 5.50$ & $19.13 \pm 7.38$ & $31.25 \pm 15.50$ \\
S7 & $76.63 \pm 27.13$ & $8.63 \pm 4.38$ & $23.00 \pm 5.75$ & $28.13 \pm 18.13$ \\
S8 & $60.50 \pm 14.75$ & $3.25 \pm 2.00$ & $19.63 \pm 6.13$ & $15.13 \pm 7.88$ \\
S9 & $53.63 \pm 19.88$ & $11.13 \pm 5.88$ & $21.13 \pm 4.88$ & $17.63 \pm 10.38$ \\
S10 & $63.50 \pm 23.25$ & $0.75 \pm 0.50$ & $17.88 \pm 3.13$ & $11.38 \pm 4.88$ \\
\hline
\end{tabular}

Table 4 : Distribution of different phytoplankton class (Mean \pm SE) during the monsoon season

\begin{tabular}{lllll}
\hline Site & Bacillarioph. & Dinoph. & Chloroph. & Cyanoph. \\
\hline S1 & $90.50 \pm 25.50$ & $8.13 \pm 3.63$ & $18.63 \pm 5.63$ & $43.63 \pm 18.13$ \\
S2 & $44.00 \pm 8.25$ & $6.25 \pm 4.25$ & $18.00 \pm 8.50$ & $15.00 \pm 8.00$ \\
S3 & $147.88 \pm 46.88$ & $25.63 \pm 16.63$ & $39.63 \pm 25.88$ & $45.25 \pm 4.25$ \\
S4 & $110.50 \pm 59.75$ & $5.13 \pm 2.38$ & $29.50 \pm 18.00$ & $35.25 \pm 15.75$ \\
S5 & $58.63 \pm 15.63$ & $7.13 \pm 3.13$ & $19.63 \pm 7.88$ & $27.75 \pm 8.50$ \\
S6 & $94.25 \pm 19.50$ & $6.88 \pm 3.13$ & $21.88 \pm 13.38$ & $20.75 \pm 12.75$ \\
S7 & $72.75 \pm 38.50$ & $9.25 \pm 6.75$ & $27.13 \pm 17.63$ & $20.75 \pm 16.25$ \\
S8 & $101.13 \pm 67.13$ & $6.50 \pm 4.25$ & $18.00 \pm 10.50$ & $13.38 \pm 6.63$ \\
S9 & $69.88 \pm 20.13$ & $11.38 \pm 3.38$ & $18.75 \pm 6.50$ & $18.88 \pm 6.63$ \\
S10 & $41.63 \pm 16.63$ & $1.38 \pm 0.63$ & $17.63 \pm 7.13$ & $11.50 \pm 6.00$ \\
\hline
\end{tabular}

Table 5: Correlation matrix relating Phytoplankton class with physico chemical parameters during the post monsoon season

\begin{tabular}{lllll}
\hline Parameters & Bacillarioph. & Dinoph. & Chloroph. & Cyanoph. \\
\hline Airtemp & $-.655^{*}$ & -.152 & $-.733^{*}$ & -.272 \\
Watertemp & -.258 & .177 & .098 & .294 \\
pH & .093 & -.049 & .184 & $.659^{*}$ \\
TDS & -.067 & .277 & .100 & .312 \\
EC & -.174 & .362 & .001 & .232 \\
Salinity & -.210 & .290 & -.090 & .254 \\
Transparency & -.144 & $-.789^{* *}$ & -.177 & -.126 \\
Lightintensity & .621 & .600 & $.650^{*}$ & .397 \\
FreeCO & .026 & .452 & .033 & -.028 \\
Alkalinity & .012 & .617 & .052 & .119 \\
Hardness & -.096 & .470 & .077 & .188 \\
DO & -.390 & $-.728^{*}$ & -.450 & -.226 \\
BOD & -.017 & $.805^{* *}$ & .097 & .281 \\
COD & .107 & $.725^{*}$ & .029 & .166 \\
Phosphate & -.160 & $.720^{*}$ & .013 & .003 \\
Nitrate & -.252 & .537 & -.116 & -.144 \\
Ammonia & -.124 & .570 & -.120 & .075 \\
Silica & -.202 & .518 & .003 & -.026 \\
\hline
\end{tabular}

Table 6: Correlation matrix relating Phytoplankton class with physico chemical parameters during the premonsoon season

\begin{tabular}{lllll}
\hline Parameters & \multicolumn{2}{l}{ Bacillarioph. Dinoph. } & \multicolumn{2}{l}{ Chloroph. Cyanoph. } \\
\hline Airtemp & -.410 & -.169 & -.447 & -.303 \\
Watertemp & $-.642^{*}$ & .128 & -.295 & -.356 \\
pH & -.216 & $-.735^{*}$ & -.033 & -.359 \\
TDS & -.212 & .375 & -.296 & -.269 \\
EC & -.168 & .332 & -.317 & -.301 \\
Salinity & -.008 & .434 & -.215 & -.154 \\
Transparency & $-.638^{*}$ & $-.815^{* *}$ & -.259 & -.407 \\
Lightintensity & .329 & .474 & .076 & -.050 \\
FreeCO2 & .590 & .623 & .459 & .254 \\
Alkalinity & $.667^{*}$ & $.859^{* *}$ & .215 & .627 \\
Hardness & $.824^{* *}$ & $.708^{*}$ & .375 & .454 \\
DO & $-.644^{*}$ & -.431 & -.139 & -.437 \\
BOD & $.671^{*}$ & $.849^{* *}$ & .439 & .374 \\
COD & .474 & $.686^{*}$ & .354 & .126 \\
Phosphate & $.724^{*}$ & $.740^{*}$ & .323 & .378 \\
Nitrate & $.655^{*}$ & .551 & .238 & .270 \\
Ammonia & $.658^{*}$ & $.689^{*}$ & .099 & .454 \\
Silica & $.728^{*}$ & $.766^{* *}$ & .140 & .562
\end{tabular}


Table-7: Correlation matrix relating Phytoplankton class with physico chemical parameters during the monsoon season

\begin{tabular}{lllll}
\hline Parameters & \multicolumn{2}{c}{ Bacillarioph. Dinoph. } & \multicolumn{2}{l}{ Chloroph. Cyanoph. } \\
\hline Airtemp & .201 & .103 & .215 & -.447 \\
Watertemp & .180 & .240 & .296 & -.361 \\
pH & -.050 & .051 & -.022 & .448 \\
TDS & .198 & .227 & .185 & -.273 \\
EC & .324 & .357 & .289 & -.184 \\
Salinity & .288 & .208 & .072 & -.301 \\
Transparency & -.307 & -.611 & -.350 & -.318 \\
Lightintensity .291 & .464 & .388 & .206 \\
FreeCO & .108 & .236 & .059 & .435 \\
Alkalinity & .179 & .281 & .305 & .422 \\
Hardness & .493 & .436 & .266 & .059 \\
DO & -.405 & -.334 & -.316 & -.573 \\
BOD & .184 & .499 & .244 & .395 \\
COD & .107 & .344 & .253 & .369 \\
Phosphate & -.056 & .138 & .027 & .208 \\
Nitrate & .384 & .587 & .376 & .404 \\
Ammonia & .141 & .175 & .214 & .380 \\
Silica & .090 & .226 & -.042 & .477 \\
\hline
\end{tabular}

Table8 : Correlation matrix relating Phytoplankton class with other during pre-monsoon

\begin{tabular}{lllll}
\hline Families & Bacillarioph. & Dinoph. Chloroph. Cyanoph. \\
\hline Bacillariophyceae & 1 & .432 & $.665^{*}$ & .616 \\
Dinophyceae & & 1 & .132 & .403 \\
Chlorophyceae & & & 1 & .347 \\
Cyanophyceae & & & & 1 \\
\hline
\end{tabular}

Table-9: Correlation matrix relating Phytoplankton class with other during monsoon

\begin{tabular}{lllll}
\hline Families & Bacillarioph. & Dinoph. & Chloroph. Cyanoph. \\
\hline Bacillariophyceae & 1 & .432 & $.665^{*}$ & .616 \\
Dinophyceae & & 1 & .132 & .403 \\
Chlorophyceae & & & 1 & .347 \\
Cyanophyceae & & & & 1 \\
\hline
\end{tabular}

Table 10 :Correlation matrix relating Phytoplankton class with other during post monsoon

\begin{tabular}{lllll}
\hline Families & Bacillarioph. & Dinoph. Chloroph. Cyanoph. \\
\hline Bacillariophyceae & 1 & .432 & $.665^{*}$ & .616 \\
Dinophyceae & & 1 & .132 & .403 \\
Chlorophyceae & & & 1 & .347 \\
Cyanophyceae & & & & 1 \\
\hline
\end{tabular}

* $5 \%$ level significant $(\mathrm{p}<0.05) ;{ }^{* *} 1 \%$ level significant $(\mathrm{p}<0.01)$.

with the physico-chemical parameters. The Bacillariophyceae showed a negative correlation with air temperature $(\mathrm{p}=-0.655)$ and DO $(\mathrm{p}=-0.390)$. The Dinophyceae showed a significant positive correlation with BOD $(\mathrm{p}=0.805)$, COD $(\mathrm{p}=0.725)$ and with phosphate $(\mathrm{p}=0.720)$ while it showed a signif icant negative correlation with transparency $(\mathrm{p}=-0.789)$ and with DO $(\mathrm{p}=-0.728)$. The Chlorophyceae showed significant correlation with light intensity $(\mathrm{p}=0.650)$ whereas it showed a significant negative correlation with air temperature $(\mathrm{p}=-0.733)$. The
Cyanophyceae showed a significant positive correlation with $\mathrm{pH}(\mathrm{p}=0.659)$.

During monsoon season, Bacillariophyceae was highest reported in $\mathrm{S}_{3}(147.88 \pm 46.88)$ and lowest in S1o $(41.63 \pm 16.63)$. The Dinophyceae was highest recorded in $S_{3}$ and lowest in S1o (1.38 \pm 0.63$)$. The Chlorophyceae and Cyanophyceae were recorded maximum in $\mathrm{S}_{3}(39.63 \pm 25.88)$ (45.25 \pm 4.25$)$ and minimum in S1o (17.63 \pm 7.13$)(11.50 \pm 6.00)$ respectively. Statistically, significant correlation was not shown by the physico-chemical parameters and phytoplankton groups during the monsoon season.

The season wise correlation analysis between phytoplankton groups also showed some statistically significant results. In the post-monsoon season, the Chlorophyceae showed a significant positive correlation with Bacillariophyceae $(\mathrm{p}=\mathrm{o.665})$. In the pre-monsoon season, the Chlorophyceae showed a significant positive correlation with Bacillariophyceae $(\mathrm{p}=\mathrm{0.834})$ and also with Cyanophyceae $(\mathrm{p}=0.725)$. In the monsoon season, the Chlorophyceae showed a significant positive correlation with Bacillariophyceae $(\mathrm{p}=0.782)$ and with Dinophyceae $(\mathrm{p}=\mathrm{o} .640)$ while Cyanophyceae showed a significant positive correlation with Bacillariophyceae $(\mathrm{p}=0.688)$ and also with Chlorophyceae $(\mathrm{p}=0.644)$. In all the seasons, the phytoplankton population (Mean \pm SE) was less in the reference site when compared to the other sites (S1-S9).

The study showed that the physico- chemical parameters like $\mathrm{DO}, \mathrm{BOD}, \mathrm{COD}$, transparency, and $\mathrm{pH}$ signif icantly influenced the distribution of phytoplankton classes. The $\mathrm{pH}, \mathrm{DO}$, alkalinity and the dissolved nutrient are important for the phytoplankton production (Sivakumar \& Kareppasmy, 2008). Plankton abundance and taxonomic diversity depend upon the supply of nutrients in natural waters (Chowdhury et al., 2007). The accumulation of organic matter from seafood waste will lead to the depletion of dissolved oxygen in the water column and reduces transparency (Mazik et al., 2005) which in turn showed a significant negative correlation with phytoplankton during the pre-monsoon and postmonsoon periods. A decrease in transparency was associated with elevated phytoplankton biomass (Cloern, 2001). In the present study, the highest plankton density was recorded during pre-monsoon season when $\mathrm{N}_{-} \mathrm{NO}_{3}$ concentrations were found to be highest. A similar positive relationship was also reported by Shukla et al. (2013). In this study, phytoplankton responded positively to the higher phosphate concentration. These findings contradicted with Patra \& Azadi (1987) who found a negative relationship between $\mathrm{P}_{-} \mathrm{PO}_{4}$ and plankton population. The physicochemical parameters significantly influenced the phytoplankton population, especially in the pre-monsoon season. During the summer season, the river water turns to more lacustrine and the additions of nutrients favoured the growth of plankton (Sileika et al., 2006). The season wise 


\section{RESEARCH ARTICLE}

correlation of the physico-chemical parameters and the phytoplankton could be used as a baseline and reference point when assessing further changes in the wetland due to the discharge of seafood waste associated pollution.

\section{References:}

Abowei, J.F.N., Ezekiel, E.N. \& Hansen, U. (2012): Effects of Water Pollution on Phytoplankton Species Composition in Koluama Area, Niger Delta Area, Nigeria. Int. J. Fish. Aquat. Sci., 1(2):134-139.

Adoni, A.D., Joshi, G., Ghosh, K., Chourasia, S.K., Vaishya, A.K., Yadav, M. \& Verma, G.H. (1985): A Work Book on Limnology. Pub. by: Department of Botany, H. S. Gaur Vishwavidyalaya, Sagar, India. 73p.

Ajuonu, N., Ukaonu, S.U., Oluwajoba, E.O., Mbawuike, B.E., Williams, A.B. \& Myade, E.F. (2011): The abundance and distribution of plankton species in the Bonny Estuary, Nigeria.Agr. Biol.J. N. Am., 2(6):1032-1037.

Akbay, N., Anul, N., Yerti, S., Soyupak, S. \& Yurteri, C. (1999): Seasonal distribution of large phytoplankton in Keban dam reservoir. Plank. Res., 21(4):771-787.

AMEC Earth and Environmental Limited (2003): Final Report of Management of wastes from atlantic seafood processing operations Submitted to: National programme of action Atlantic regional team. SEE. 135p.

Anene, A. (2003): Techniques in hydrobiology, 174-189 pp. In: Eugene NO \& Julian OO (Eds), Research Techniques in Biological and Chemical Sciences. Pub. by: Springfield Publishers.

APHA (2005): Standard Methods for the Examination of Water and Wastewater. 21st Edition, Pub. by: American Public Health Association/American Water Works Association/Water Environment Federation, Washington DC.

Begon, M., Harper, J.D. \& Townsend, C.R. (2014): Essentials of Ecology (4th Edition). Pub. by: Wiley Wiley \& Sons, Inc., 48o pp.

Bellinger, G.E., \& Siegee, D.C. (2010): Fresh Water Algae: Identification and Use as Bio-indicators. Pub. by: Wiley Blackwell Chichester, UK. 271 p.

Cloern, J.E. (2001): Our evolving conceptual model of the coastal eutrophication problem. Mar. Ecol. Prog. Ser., 210:223-253.

Chowdhury, M.M.R., Mondol, M.R.K., \& Sarker, C. (2007): Seasonal variation of plankton population of Borobila beel in Rangpur district. Univ. J. Zool. Rajshahi Univ., 26:49-54.

Davies, O.A., Abowei, J.F.N \& Tawari, C.C. (2009): Phytoplankton community of Elechi Creek, Niger Delta, Nigeria: A nutrient polluted tropical creek. Am. J.Appl. Sci., 6(6):1143-1152.

Hamid, M., Masoud, A., Masoud, H. \& Fardin, B. (2010): An assessment of Fish Processing plant Discharge Effluent on The Tizab River. World Acad. Sci., Eng. Technol.,47:146 p.

Lee R E. (1999): Psychology. Pub. by: Cambridge University Press, New York, 614 pp.

Mazik, K., Burdon, D. \& Elliott, M. (2005): Seafood-waste disposal at sea-A scientific review. Report to The Sea Fish Industry Authority, Institute of Estuarine and Coastal Studies, University of Hull, UK.

Moss, B.(1995): Ecology of Fresh Waters: Man and Medium.
Ambient Science, 2019: Vol. 06(1); 21-25 DOI:10.21276/ambi.2019.06.1.ra03

Pub. by: Blackwell Science Inc., 333pp.

Newell, R.C. \& Newell, G.E. (1986): Marine Plankton A Practical Guide. Pub. by: Hutchinson Educationa, London. 206 pp.

Nwankwo, D.I. (2004): Studies on the Environmental preference of blue-green algae (cyanophyta) in Nigeria coastal waters. Niger. Environ. Soc. J., 2(1):44-51.

Palmer, C.M. (1980): Signif icance of algae. In: Algae and Water Pollution: The Identification, Significance, and Control of Algae in Water Supplies and in Polluted Water. Pub. by: Castle House Publications, London. 123 pp.

Patra, R.W.R. \& Azadi, M.A. (1987): Ecological studies on the planktonic organisms of the Halda River. Bangladesh J. Zool., 15(2): 109-123.

Peerapornpisal, Y., Sonthichai, W., Somdee, T., Mulsin, P. \& Rott, E. (1999): Water quality and phytoplanktonin the Mae Kuang Udomtara Reservoir, Chiang Mai, Thailand. Chiang Mai J. Sci., 26(1):25-43.

Rai, L.C. \& Kumar, H.D. (1976): Studies on the seasonal variation in the algal communities of pond polluted with fertilizer factory effluent. Indian J. Ecol., 4(2):124-131.

Rawson, D. S. (1956): Algal indicators of trophic lake types. Limnol. Oceanogr., 1 (1):18-25.

Remani, K.N., Venugopal, P., Saraladevi, K., Lalitha, S. \& Unnithan, R.V. (1980): Sediments of Cochin backwaters in relation to pollution. Indian J. Mar. Sci., 9(2):111-114.

Roelke, D. \& Buyukates Y. (2002): Dynamics phytoplankton succession coupled to species diversity as a system level tool for study of Microcystis population dynamics in eutrophic lakes. Limnol. Oceanogr., 47(4):1109-1118.

Santhanam R., N Ramanathan, K Venkataramanuja and G Jegatheesan. (1987): Phyto- plankton of the Indian Seas. Daya publishing House, Delhi. 134 Pp. BOOK

Saraladevi, K., Venugopal, P., Remani, K.N., Lalitha, S., \& Unnithan, R.V. (1979): Hydrographic features and water quality of Cochin backwaters in relation to industrial pollution. Indian J. Mar. Sci., 8:141-145.

Shukla, P., Preeti \& Singh, A. (2013): A Seasonal Variations of Plankton Population of Maheshara Lake in Gorakhpur, India. World J. Zool., 8 (1): o9-16, 2013. World J. Zool., 8 (1): 09-16.

SIFFS. (2002): Globalisation and Seafood Trade Legislation: The effect on poverty in India. Pub. by: South Indian Federation of Fishermen Societies, India. 71 pp.

Sileika, A., Lnacke, P., Kutra, S., Gaigals, K. \& Berankiene, L. (2006): Temporal and spatial variation of nutrient levels in the Nemunas River (Lithuania and Belarus). Environ. Monit. Assess., 122(1-3):335-354.

Sivakumar, K. \& Kareppasmy, R. (2008): Factor affecting productivity in a Reservoir of Tamilnadu, especially crustaceans and rotifer as indicator of India. IDOSI Publication. Am. Euras. J. Bot., 1(3): 99-103. 